\title{
Akses dan Kontrol Perempuan Terhadap Interior RumahTinggal Studi Kasus : Kawasan Hunian Karangwaru Riverside
}

\author{
Galuh Marta Dhaniswara', Artbanu Wishnu Aji ${ }^{2}$, Danang Febriyantoko ${ }^{3}$ \\ Program Studi Desain Interior, Institut Seni Indonesia Yogyakarta \\ Email: dhanisgaluh@gmail.com
}

\begin{abstract}
Abstrak
Perkembangan jaman telah membawa pergeseran peran perempuan di berbagai bidang sebagai bagian dari upaya memperoleh akses dan kontrol terhadap sumber daya, ekonomi, politik, sosial dan budaya. Dalam upayanya, untuk mengatur serta meningkatkan rasa percaya diri dalam memecahkan permasalahan serta kebutuhan dalam berbagai bidang telah membawa merubah paradigma perempuan untuk turut berperan aktif didalam maupun diluar rumah tinggalnya. Penelitian ini bertujuan untuk mengetahui bentuk pengaruh keaktifan perempuan dalam lingkungan terhadap rumah tinggal serta interpretasinya terhadap bentuk akses, kontrol, maupun pola teritori keruangan dalam rumah tinggal. Kawasan Karangwaru Riverside sebagai kawasan hunian berkembang dengan pengaruh kuat kegiatan masyarakat yang mampu membentuk kawasannya secara mandiri memiliki keragaman jenis keaktifan dalam masyarakat, utamanya pada kaum perempuan dipilih sebagai kawasan studi kasus. Pengumpulan data penelitian dilakukan berdasarkan observasi layout serta hasil wawancara dari 10 purposive sample yang mewakili 2 jenis keaktifan perempuan terhadap lingkungannya dan dianalisis berdasarkan metode analisis Harvard. Hasil penelitian, memperlihatkan bahwa berdasarkan sifat dan jenis keaktifan perempuan terhadap lingkungan sekitar ruang- hidupnya telah membentuk perbedaan terhadap besaran profil kegiatan akses ruang dan jangkauan kontrol harian perempuan terhadap masing-masing ruang dalam rumah tinggal. Melalui perbedaan akan skala penggunaan dan kegiatan kontrol perempuan dalam hunian, membentuk pengaruh terhadap pola konstruksi teritori keruangan dan ruang prioritas perempuan dalam rumah tinggal.
\end{abstract}

Kata kunci: Perempuan, Akses dan Kontrol, Teritori

\begin{abstract}
The development of the era has brought a shift in the role of women in various fields as part of the effort to gain access to and control over resources, economy, politics, society, and culture. By their efforts to regulate and increase self-confidence in solving problems and needs in those various fields have led to changing the paradigm of women to take an active role in and outside their homes. This study aims to determine the shape of the influence of women's activeness in the environment on the residence and its interpretation of the forms of access, control, and spatial territorial patterns of the house. Karangwaru Riverside area is one of a developing residential area with strong influence from community activities that have the ability to form an area independently and has a variety of types of activity in the community especially for women chosen as a sample of the observation area. The research data was collected based on layout observations and interviews from 10 purposive samples representing 2 types of women's activeness towards their environment and were analyzed based on the Harvard analysis method. The results showed that based on the type of women's activity in the environment around their living space, has formed differences in the different scales of the profile of daily space access activities and the range of control over each room in the house. Through the differences in each scale of use and
\end{abstract}


control activities of women in their house, it forms an influence on the pattern construction of women's spatial territories and priority spaces in the residence.

Keywords: Women, Access and Control, Territory

\section{Pendahuluan}

Perempuan sebagai bagian dari makhluk sosial tidak pernah terlepas dari lingkungan sekitar dan saling memberikan pengaruhnya terhadap ruang hidupnya. Melalui perkembangan jaman dan kebutuhan, serta luasan kegiatan atas keterlibatan perempuan terhadap lingkungan sekitarnya semakin memperoleh kesetaraan serta kebebasan dengan semakin besarnya peluang perempuan untuk bergabung dalam organisasi sosial. Perkembangan keaktifan perempuan diluar rumah telah menyangkut pada perkembangan psikologis dari perempuan, presepsi pengamatan terhadap area tinggal, setting prioritas kebutuhan, dan gaya hidup secara tak sadar telah masuk dalam proses sintesis berkegiatan didalam rumah tinggal. Sebagaimana kajian arsitektur berwawasan perilaku oleh (Tandal, Antonius N dan Egam, I Pingkan P., 2011) memaparkan bahwa secara psikologis, lingkungan dapat mempengaruhi manusia. Manusia tinggal atau hidup dalam suatu lingkungan sehingga manusia dan lingkungan saling berhubungan dan saling mempengaruhi.

Keterkaitan antara perempuan dan lingkungan serta kegiatan yang berkembang di diantaranya menjadi sebuah bagian dari intrepretasi perilaku pengguna dan bentuk dalam ruang di rumah tinggal. (Haryadi, B. Setiawan., 2010) menjelaskan ruang sebagai bagian dari komponen arsitektur merupakan wadah manusia dalam mempersonalisasikan kegiatan manusia dan lingkungannya. Perilaku manusia yang dalam hal ini merupakan perilaku perempuan kemudian menjadi sebuah bagian dalam arsitektur dan menstimulasi keterkaitan melalui dialetik antar ruang dengan manusia dan diterjemahkan melalui profil subjek pengguna yang memanfaatkan, mengakses serta melakukan kegiatan pengaturan dalam ruang.

Dihubungkan melalui teori logika ruang, (Hiller, B., 1996) mengemukakan bahwa faktor stimulasi kegiatan lingkungan dan penerimaan perilaku baru atau adopsi perilaku manusia kedalam arsitektur membentuk keterkaitan antara hubungan manusia dan space. Bentuk adopsi hubungan space atau ruang dengan manusia secara mendasar tercermin melalui level konfigurasi space dan aktifitas individual dalam sebuah arsitektur. Pada kesempatan lain Hiller dan Hanson mengemukakan bahwa susunan ruang dalam bangunan, batas, zona atau teritori, dan sebagainya, hingga keadaan fisik dari kelompok ruangan akan membentuk pola dan dikenali melalui logika internal (Hillier, B., \& Hanson, J., 1984)

\section{Metode}

Penelitian ini merupakan penelitian dengan metode kualitatif. (Moleong, L. J., 2010)menjelaskan bahwa sumber data utama dalam penelitian kualitatif ialah kata-kata dan tindakan. Kata-kata dan tindakan merupakan sumber data yang diperoleh dari lapangan dengan mengamati atau mewawancarai subjek penelitian dan membandingkan dengan observasi terhadap objek penelitian yang dalam hal ini merupakan rumah tinggal.

Responden atau subjek penelitian menggunakan purposive sample yakni 10 perempuan yang tinggal di kawasan hunian Karangwaru Riverside. Subjek penelitian kemudian dikelompokkan berdasarkan 2 kategori untuk memberikan batas-batas observasi serta ulasan akan perbandingan kelompok data yang jelas. Pengelompokan responden ini adalah berdasarkan jenis peran dan keaktifan subjek perempuan dalam kegiatan masyarakat. Penunjukan responden atau sample didasarkan akan rekomendasi yang didapat melalui diskusi dengan tokoh masyarakat yang ada di kawasan hunian Karangwaru Riverside. 
Tabel 1 Profil Responden

(Sumber : Dokumen Pribadi, 2020)

\begin{tabular}{|c|c|l|c|c|l|}
\hline \multicolumn{3}{|c|}{ Subjek Perempuan Aktif } & \multicolumn{3}{c|}{ Subjek Perempuan Kurang Aktif } \\
\hline Nama & Umur & \multicolumn{1}{|c|}{ Status } & Nama & Umur & \multicolumn{1}{c|}{ Status } \\
\hline A1 & 64 & $\begin{array}{l}\text { Penggerak lingkungandan } \\
\text { Posyandu }\end{array}$ & B1 & 50 & Asisten rumah tangga \\
\hline A2 & 51 & $\begin{array}{l}\text { KRA, PKK, Penggerakremaja } \\
\text { dan Posyandu }\end{array}$ & B2 & 78 & Ibu rumah tangga \\
\hline A3 & 49 & $\begin{array}{l}\text { Penggerak Posyandudan } \\
\text { Lansia }\end{array}$ & B3 & 44 & Apoteker \\
\hline A4 & 42 & PKK & B4 & 40 & Ibu rumah tangga \\
\hline A5 & 50 & Humas Masjid & B5 & 41 & Asisten rumah tangga \\
\hline
\end{tabular}

Data dianalis dengan menggunakan dengan teknik koding data melalui hasil paparan wawancara dan diolah melalui tabel modifikasi Harvard sebagai media pemetaan profil akses dan kontrol pada setiap sampel populasi. Pemetaan analisis dalam tabel modifikasi Harvard terhadap akses dan kontrol dalam masing-masing ruang dihimpun melalui wawancara semi terstruktur kepada masingmasing kelompok sample perempuan dan salah-satu pengguna lainnya dalam hunian (suami atau anak). Data secara umum meliputi uraian kegiatan rutin harian (behavioris) atas ruang oleh perempuan dan perbandingan lama akses melalui urian kegiatan harian subjek pengguna lainnya. Hasil analisis perbandingan profil kemudian ditampilkan dalam bentuk tabel perbandingan sederhana dan disandingkan terhadap data observasi lapangan tiap sampel rumah tinggal untuk menerjemahkan pola territorial layout keruangan tiap kelompok sampel.

\section{Pembahasan}

Kegiatan manusia khususnya perempuan dengan lingkungannya membentuk kerangka sosial dan turut dipengaruhi oleh dinamika akses serta kontrol dalam berbagai bidang yang kemudian dipahami dan melekat sebagai konstruksi sosial dan budaya. Paradigma perempuan yang merupakan salah-satu pokok persoalan dilingkungan saat ini telah mengalami dinamika pergeseran dimana asumsi perempuan yang terbatas hanya mengurus kegiatan domestik dan berperan sebagai tangan kedua telah berubah dan menyesuaikan dengan perubahan persoalan serta kenyataan yang muncul dalam kehidupan masyarakat. Peran perempuan yang telah meluas dan merubah paradigma serta perspektif perempuan terhadap hak, kewajiban dan kebutuhan serta perilaku sosial didalam dan diluar hunian. Secara umum perubahan peran perempuan diberbagai bidang sebagai upaya memperoleh akses dan kontrol terhadap sumber daya, ekonomi, politik, sosial dan budaya merupakan bentuk perempuan untuk mengatur diri dan partisipasi dalam memecahkan masalah serta kebutuhan sehingga mampu membangun impresi serta konsep didalam suatu lingkungan.

Keterhubungan antara arsitektur yang dalam hal ini rumah tinggal sebagai wadah kegiatan atau ruang manusia menurut (Haryadi, B. Setiawan., 2010) telah turut dipengaruhi oleh lingkungan serta dinamika kegiatan manusia didalamnya. Disebutkan juga melalui teori psikologi lingkungan dalam penelitian (Tandal, Antonius N dan Egam, I Pingkan P., 2011), bahwa lingkungan dapat mempengaruhi manusia secara psikologis dan bahwa manusia yang tinggal atau hidup dalam suatu lingkungan sehingga keduanya akan saling berhubungan dan saling mempengaruhi.

Sebuah teori dalam penelitian Environmental Psychology Scope oleh (Gifford, R., 2007) secara umum menyebutkan bahwa pengaturan, kekuatan individu serta norma sosial dan kultural dalam lingkungan melalui kebiasaan serta proses kognisi yang terstruktur dalam suatu lingkungan dapat melahirkan stimulasi pembentukan atau perubahan interpretasi sikap terhadap ruang hidup. 
Perbedaan akan bentuk interpretasi perempuan sebagai individu dalam menyikapi lingkungan dan keterhubungannya terhadap lingkungan kemudian menyebabkan perbedaan bentuk stimulasi perilaku dan profil aktifitas dalam ruang tinggalnya

Penelitian ini berfokus kepada pengkajian studi kasus untuk mengemukakan analisis profil akses dan kontrol serta pengaruh pola teritori keruangan atas bentuk interpretasi profil keaktifan dan keterhubungan perempuan disekitar lingkungan rumah tinggalnya. Data dibandingkan melalui pengelompokan berdasarkan kategori keaktifan perempuan terhadap kegiatan disekitar Karangwaru Riverside.

\section{Akses dan Kontrol}

- Area Penerimaan Tamu

Tabel 2. Profil Akses dan Kontrol Perempuan Terhadap Area Penerimaan Tamu (Sumber : Dokumen Pribadi, 2020)

\begin{tabular}{|c|c|c|}
\cline { 2 - 3 } \multicolumn{1}{c|}{} & Perempuan Aktif & Perempuan Kurang Aktif \\
\hline Akses & $\mathrm{P} \geq \mathrm{L}$ & $\mathrm{P}<\mathrm{L}$ \\
\hline Kontrol & $\mathrm{P}=\mathrm{L}$ & $\mathrm{P}$ \\
\hline
\end{tabular}

Area penerimaan tamu dalam rumah tinggal perempuan aktif cenderung berada di area terbuka atau pada bagian depan hunian dan memiliki pemisah (room boundary) yang cukup jelas terhadap area lainnya dalam hunian. Kegiatan akses perempuan di area ini cenderung tinggi dimana profil akses didasarkan atas kecenderungan terhadap pekerjaan yang berhubungan dengan kegiatan sosial dan sering kali mendapati tamu di dalam rumah. Secara garis besar, tingginya kegiatan akses dan kontrol area penerimaan tamu pada kelompok perempuan aktif masih dilakukan bersamaan dengan seluruh anggota keluarga dan penggunaannya tidak terkhusus. Melalui kegiatan akses dan kontrol yang bersamaan. Perempuan aktif tidak menunjukkan subjektifitas ruang melalui penampilan identitas sebagai pengguna utama dengan jelas baik melalui citra, skala pengukuran ruang, dan pengisi ruang walaupun dominan melakukan akses didalamnya. Ruangan dipergunakan secara holistik dengan fungsi ruang yang kompleks serta memiliki pola layout ruang sosiopetal, yakni ruang dengan tatanan yang cenderung dapat menstimulasi interaksi sosial. Pola ruang sosiopetal sering ditandai melalui pola penataan kursi maupun sofa yang berpola "L" atau "U".

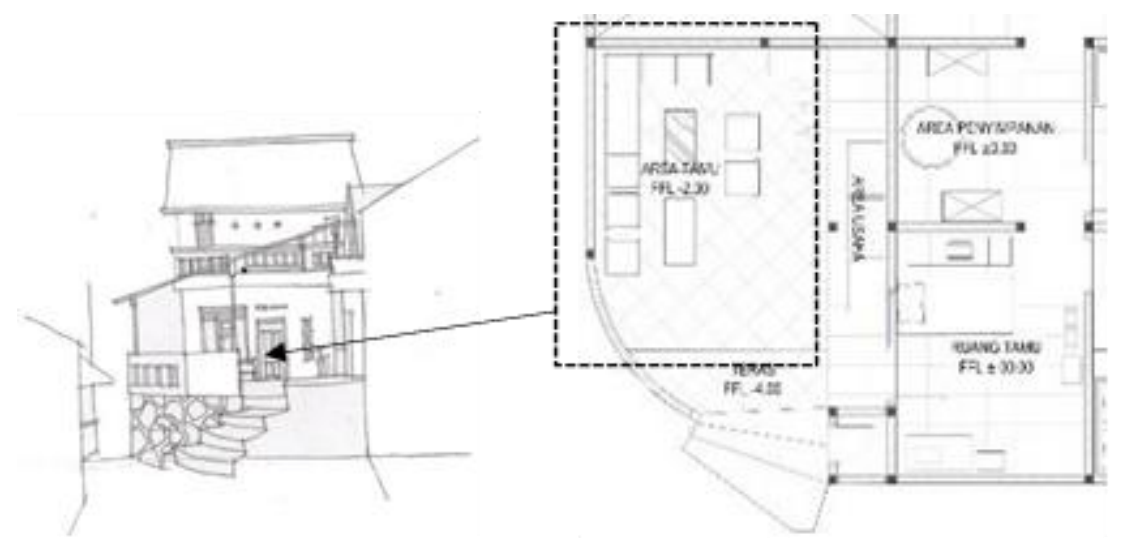

Gambar 1. Letak dan Pola Layout Area Penerimaan Tamu Rumah Tinggal Perempuan Aktif (Sumber : Dokumen Pribadi, 2020) 
Area penerimaan tamu di rumah tinggal pada perempuan kurang aktif juga berada terletak di bagian depan hunian dan umumnya memiliki beberapa fungsi ruang. Selain fungsi utama ruang sebagai area penerimaan tamu, area ini lebih sering diakses perempuan sebagai area dengan fungsi lain yang meliputi area bersantai, area setrika, dan area penyimpanan. Ruangan secara umum diakses perempuan dalam skala penggunaan ruang kecil hingga menengah dimana penggunaan ruang dalam hunian tidak digunakan dalam waktu yang lama. Hal tersebut dikarenakan cenderung rendahnya frekuensi tamu yang datang ke dalam hunian perempuan kurang aktif. Berbalik dengan kegiatan akses, perempuan dalam kelompok ini memiliki kontrol penuh akan area penerimaan tamu baik secara harian maupun berkala. Didapati bahwa pola penataan ruang pada area ini juga menggunakan pola ruang sosiopetal yang ditandai melalui penataan kursi maupun sofa dominan berpola "L", namun karena fungsi ruang dominan bergeser sebagai area simpan dan kegiatan selain menerima tamu, pola penataan ruang di kelompok rumah tinggal ini cenderung berubahubah dan dilakukan langsung oleh perempuan.

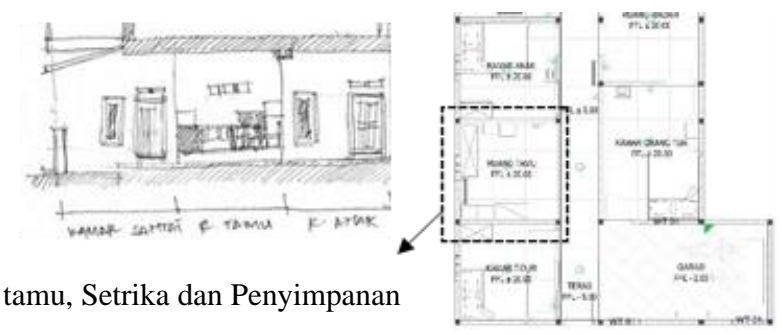

Gambar 2 Letak dan Pola Layout Area Penerimaan Tamu Rumah Tinggal Perempuan Kurang Aktif (Sumber : Dokumen Pribadi, 2020)

- Ruang Keluarga

Tabel 3. Profil Akses dan Kontrol Perempuan Terhadap Area Keluarga (Sumber : Dokumen Pribadi, 2020)

\begin{tabular}{|c|c|c|}
\cline { 2 - 3 } \multicolumn{1}{c|}{} & Perempuan Aktif & Perempuan Kurang Aktif \\
\hline Akses & $\mathrm{P}<\mathrm{L}$ & $\mathrm{P} \geq \mathrm{L}$ \\
\hline Kontrol & $\mathrm{P} \geq \mathrm{L}$ & $\mathrm{P}>\mathrm{L}$ \\
\hline
\end{tabular}

Ruang keluarga pada kelompok sampel perempuan sebagai subjek aktif merupakan ruang dengan akses perempuan terhadap ruang tidak besar. Area cenderung lebih banyak diakses oleh anggota keluarga lainnya dan kegiatan di dalam area ini meliputi kegiatan minor yakni sebagai area entertainment. Walaupun kegiatan akses ruang yang singkat, pada kelompok ini kegiatan kontrol harian ruang masih dikendalikan dibawah kontrol perempuan namun secara khusus pada penerapannya perempuan lebih banyak memberi pendampingan serta pengawasan kegiatan pembersihan dan pengorganisasian barang simpan dan barang sering pakai oleh pengguna yang lebih dominan. Dilain hal, kegiatan akses ruang keluarga oleh perempuan kurang aktif cenderung lebih tinggi bersamaan dengan anggota keluarga lainnya. Kegiatan kontrol ruang secara dominan juga dikendalikan oleh perempuan. 
- Ruang Makan

Tabel 4. Profil Akses dan Kontrol Perempuan Terhadap Ruang Makan (Sumber : Dokumen Pribadi, 2020)

\begin{tabular}{|c|c|c|}
\hline & Perempuan Aktif & Perempuan Kurang Aktif \\
\hline Akses & $\mathrm{P} \geq \mathrm{L}$ & $\mathrm{P}>\mathrm{L}$ \\
\hline Kontrol & $\mathrm{P}>\mathrm{L}$ & $P$ \\
\hline
\end{tabular}

Ruang makan dalam hunian kelompok sampel perempuan sebagai subjek aktif memiliki fungsi ruang yang terbagi dalam beberapa fungsi ruang. Secara umum, ruang makan dipergunakan sebagai area saji, area transisi antara ruang publik dan ruang privat pada hunian, dan sebagai area simpan barang sering dan jarang pakai. Kegiatan akses perempuan sedikit lebih tinggi dari anggota keluarga lainnya namun secara umum, lama akses ruang cenderung singkat karena keluarga pada kelompok ini melakukan kegiatan menyantap makanan jarang di ruang makan dan pada waktu yang juga jarang bersamaan. Secara keseluruhan, perempuan juga merupakan individu yang lebih dominan melakukan aktivitas kontrol ruangan, khususnya berkaitan dengan pengaturan barang simpan dan penataan sajian makanan. Dilain hal, perempuan kurang aktif memiliki akses yang lebih panjang dari pada anggota keluarga lainnya. Kegiatan akses yang dilakukan meliputi kegiatan bersantai dan kegiatan menyiapkan bahan masakan karena dominan ruang makan pada kelompok ini menyatu dengan dapur. Kegiatan kontrol ruang makan di kelompok ini secara utuh dilakukan oleh perempuan sebagai bagian dari kegiatan kontrol harian. Kegiatan kontrol ruang yang paling digemari perempuan pada area ini yakni melalui kegiatan menata pola penataan meja dan kursi, penataan barang simpan, serta kebebasan pemilihan taplak pelapis meja oleh perempuan.

- Dapur dan Kamar Mandi

Tabel 5. Profil Akses dan Kontrol Perempuan Terhadap Dapur dan Kamar Mandi (Sumber : Dokumen Pribadi, 2020)

\begin{tabular}{|c|c|c|}
\cline { 2 - 3 } \multicolumn{1}{c|}{} & Perempuan Aktif & Perempuan Kurang Aktif \\
\hline Akses & $\mathrm{P}=\mathrm{L}$ & $\mathrm{P}=\mathrm{L}$ \\
\hline Kontrol & $\mathrm{P}<\mathrm{L}$ & $\mathrm{P}$ \\
\hline
\end{tabular}

Kegiatan akses dan kontrol di area dapur dan kamar mandi pada rumah tinggal perempuan aktif dilakukan oleh subjek beragam, dimana terdapat pembagian kegiatan domestik antara perempuan dengan laki-laki melalui kegiatan akses dan kontrol harian di kedua area ini. Pembagian peran paling dominan nampak melalui kegiatan akses dapur yang meliputi kegiatan menyiapkan makanan pada siang hari serta kegiatan kontrol pembersihan dapur dan kamar mandi harian dominan dilakukan oleh subjek laki-laki atau suami dalam hunian. Faktor dominan dari pembagian kegiatan akses dan kontrol ini akibat perempuan dalam kelompok ini lebih banyak bekerja dan terlibat dalam kegiatan sosial disekitar lingkungannya di siang hari. Dilain hal, perempuan kurang aktif secara berdampingan memiliki kegiatan akases yang lebih seimbang di area dapur dan kamar mandi. Kegiatan akses yang meliputi kegiatan menyiapkan makanan utama dominan dilakukan 
perempuan, namun laki-laki pada kelompok ini secara berkala juga mengakses dapur untuk sekedar meracik kopi dan menghangatkan makanan. Walaupun kegiatan akses dilaksanakan bersamaan, kegiatan kontrol kedua ruang masih secara harian dan berkala dikendalikan oleh perempuan.

- Area Cuci dan Jemur

Tabel 6. Profil Akses dan Kontrol Perempuan Terhadap Area Cuci dan Jemur (Sumber : Dokumen Pribadi, 2020)

\begin{tabular}{|c|c|c|}
\hline & Perempuan Aktif & Perempuan Kurang Aktif \\
\hline Akses & $\mathrm{P} \geq \mathrm{L}$ & $\mathrm{P}>\mathrm{L}$ \\
\hline Kontrol & $\mathrm{P}<\mathrm{L}$ & $P$ \\
\hline
\end{tabular}

Tidak jauh berbeda dengan kegiatan dometik di area dapur dan kamar mandi, didapati bahwa kegiatan di area cuci dan jemur secara harian maupun berkala di kelompok hunian dengan perempuan aktif lebih banyak dilakukan oleh laki-laki. Pemindahan kuasa serta kegiatan di area tersebut masih disebabkan sebagai kegiatan penyesuaian dari tuntutan waktu dan fokus peran perempuan yang telah terbagi di luar hunian. Berangkat dari kegiatan penyesuaian tersebut, kemudian laki-laki mengisi kekosongan peran harian dari kegiatan cuci dan jemur serta menjadi tokoh dominan dari akses dan kontrol kedua area ini. Kegiatan yang berkenaan dengan pemilihan dan penataan unsur pengisi ruang dan pendukung kegiatan dalam kedua area ini kemudian juga banyak ditentukan oleh laki-laki sebagai pengguna utama. Berdasarkan peletakannya, area cuci dan jemur pada hunian kelompok ini dominan berada di area terbuka baik di bagian depan maupun lantai 2 yang mudah dipantau pengguna dari luar hunian. Sedangkan pada hunian dengan perempuan sebagai subjek kurang aktif pada kegiatan sosial, baik kegiatan cuci dan jemur serta pengaturan areanya cenderung dilakukan oleh perempuan. Letak kedua area ditentukan berdasarkan kainginan perempuan dan berada dominan diarea tertutup atau bagian belakang hunian.

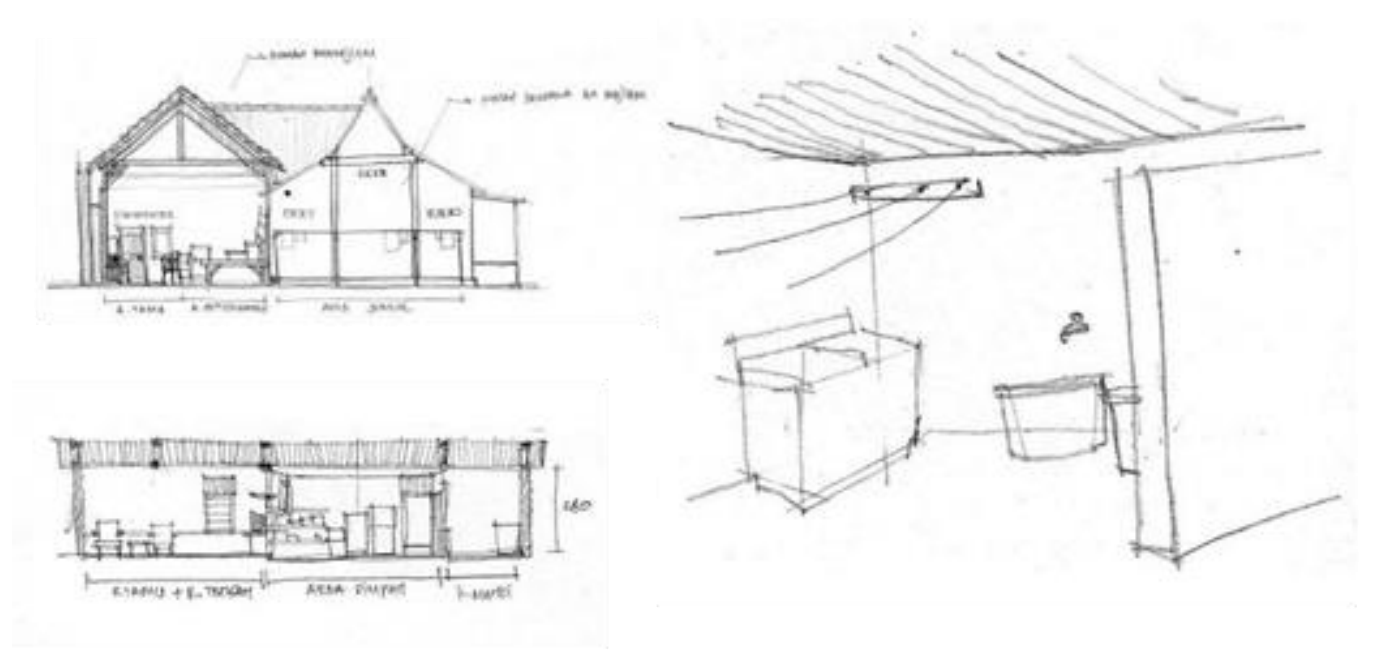

Gambar 3. Area Cuci dan Jemur Rumah Tinggal Perempuan Kurang Aktif (Sumber : Dokumen Pribadi, 2020) 
Tabel 7. Profil Akses dan Kontrol Perempuan Terhadap Kamar Tidur (Sumber : Dokumen Pribadi, 2020)

\begin{tabular}{|c|c|c|}
\hline & Perempuan Aktif & Perempuan Kurang Aktif \\
\hline Akses & $\mathrm{P} \leq$ Pengguna & $\mathrm{P} \geq$ Pengguna \\
\hline Kontrol & $\mathrm{P}=$ Pengguna & $\mathrm{P}>$ Pengguna \\
\hline
\end{tabular}

Kamar tidur di rumah tinggal kelompok perempuan aktif diposisikan sebagai area privat yang diakses secara personal hanya oleh masing-masing pengguna utama ruang. Kegiatan kontrol oleh perempuan pada kegiatan sehari-hari di area ini memiliki kendali yang meliputi kegiatan penataan penyimpanan dalam ruang dan pembersihan ringan secara harian. Kegiatan pengorganisasian penyimpanan tiap kamar dikendalikan setara dengan kontrol pengguna utama dan secara langsung perempuan hanya melakukan kegiatan kontrol akan barang tekstil yang meliputi pakaian, taplak meja, seprei, dan curtain. Kaitannya dengan penataan dan pengendalian barang pribadi yang meliputi buku, perlengkapan pekerjaan, dan koleksi tiap anggota keluarga dikendalikan secara mandiri oleh masing-masing individu di dalam kamar. Pelimpahan kegiatan pengendalian barang pribadi dilakukan perempuan sebagai bentuk penghargaan aspek privasi dan sebagai edukasi dalam aspek tanggung jawab atas kepemilikan tiap individu akan barang yang secara spesifik dipergunakan. Kegiatan pengelolaan ruang lainnya yang berkaitan dengan penataan unsur estetik ruang juga masih dikendalikan oleh perempuan. Dalam hal kontrol unsur estetika, perempuan memiliki kendali dominan utamanya dalam penentuan warna dan motif seprei dan curtain. Dominan dari setiap perempuan aktif memiliki kecenderungan untuk memilih penggunaan warna pastel dan lembut, sedangkan dalam hal motif tidak terdapat spesifik motif yang dipilih dan hanya berdasarkan ketersediaan. Kegiatan kontrol lainnya yang berkenaan dengan penataan unsur pengisi pada ruang, hunian dengan perempuan aktif dominan ditentukan secara bersama melalui sebuah kesepakatan anggota keluarga. Dilain-hal, pada kelompok hunian dengan perempuan kurang aktif di lingkungan sekitar, didapati bahwa walaupun berdasarkan sifat ruang, kamar sebagai area privat, kegiatan kontrol tiap kamar secara umum masih berada di bawah kendali perempuan. Aktivitas pengendalian ruangan yang dilakukan pada tiap kamar meliputi pembersihan harian, penataan organisasi furnitur, hingga penyimpanan dalam lemari. Melalui kegiatan pengendalian yang dilakukan perempuan menyeluruh pada tiap kamar menjadikan perempuan memiliki akses khusus setiap harinya di luar pengguna utama dalam ruang tersebut. Kegiatan pengendalian ruang yang berkaitan dengan penataan unsur estetik ruang juga masih dikendalikan oleh perempuan. Dalam hal kontrol unsur estetika, perempuan memiliki kendali dominan utamanya dalam penentuan warna dan motif seprei dan curtain. Kegiatan akses yang dilakukan oleh perempuan sehari-hari pada tiap ruang umumnya dilakukan dalam waktu yang relatif singkat namun dalam frekuensi harian yang cukup tinggi.

- Area Tambahan (Area Usaha, Area Hobi atau Peliharaan, Area Kerja)

Tabel 8. Profil Akses dan Kontrol Perempuan Terhadap Area Tambahan (Sumber : Dokumen Pribadi, 2020)

\begin{tabular}{|c|c|c|}
\cline { 2 - 3 } \multicolumn{1}{c|}{} & Perempuan Aktif & Perempuan Kurang Aktif \\
\hline Akses & $\mathrm{P}>\mathrm{L}$ & $\mathrm{P}=\mathrm{L}$ \\
\hline Kontrol & $\mathrm{P} \geq \mathrm{L}$ & $\mathrm{P} \geq \mathrm{L}$ \\
\hline
\end{tabular}


Pada rumah tinggal dengan perempuan aktif didapati bahwa dominan ruang tambahan adalah meliputi area peliharaan dan area kerja. Pada kelompok ini, keluarga dengan perempuan aktif secara langsung dan tak langsung melakukan kegiatan penambahan area serta menyesuaikan dengan kebutuhan atas aktivitas bekerja di dalam rumah. Kegiatan pembentukan area tambahan dilakukan melalui pemanfaatan ruang yang telah tersedia pada hunian dan menggandakan fungsi ruang sehingga dapat memenuhi kebutuhan aktivitas tambahan di atas aktivitas semula. Pemanfaatan ruang tertentu terhadap fungsi ganda dalam ruang dilakukan perempuan secara sederhana dengan menghadirkan furnitur tambahan seperti meja sebagai syarat penunjang kegiatan dan ditata berdampingan dengan furnitur utama dalam ruang semula. Kaitannya dengan kegiatan pengadaan dan kontrol, perempuan aktif memiliki melakukan pengadaan secara mandiri dan melakukan penataan sebagai tanggung-jawab atas kebutuhan area sebagai ruang personal dan penggunaan barang pribadinya. Dilain hal, ditemui area tambahan rumah tinggal kelompok perempuan kurang aktif dominan merupakan area peliharaan dan area usaha. Secara umum, area tambahan pada kelompok rumah tinggal ini merupakan area yang dominan digagas oleh laki-laki khususnya untuk area peliharaan. Terdapat pula area tambahan hunian yang diusulkan atas keinginan perempuan pada kelompok ini yakni cenderung merupakan area tambahan yakni berupa area usaha yang berbentuk toko, dimana merupakan usaha perempuan dalam membantu kegiatan perekonomian keluarga dan juga menambah kegiatan di waktu luangnya. Umumnya, area tambahan baik area usaha maupun peliharaan berada di bagian depan hunian dan sifatnya semi terbuka. Secara umum kegiatan kontrol yang mliputi kegiatan pembersihan di area tambahan hunian kelompok ini masih berada di bawah kendali dan pengawasan perempuan, namun kegiatan pengendalian ruang tambahan secara lebih khusus seperti penataan kendang dan pengendalian kebutuhan ruang secara mandiri dilakukan oleh pengguna ruang dominan sebagai bentuk tanggung jawab akan pengadaan ruang personal dan hobi pribadinya.

\section{Teritori Subjek Perempuan terhadap Rumah Tinggal}

Perbedaan perilaku pada masing-masing kelompok perempuan sebagai subjek pengguna dan berdampingan dengan pengguna lain secara tak langsung mempengaruhi skala kegiatan perempuan dan ruang huninya. Mengacu pada praktik stimultan kegiatan serta profil akses dan kontrol ruang sebagai bagian dari perilaku subjek perempuan terhadap huniannya, membentuk dinamika teritorial yang berupa bubble penggolongan antar ruang. Bubble territorial didasarkan melalui profil aktivitas yang terjadi yang melibatkan perbedaan akses dan kontrol perempuan yang dikaitkan dengan keterlibatan personal, involvement, kedekatan dengan kehidupan sehari-hari individu dalam rumah tinggal, dan frekuensi penggunaan terhadap masing-masing ruang

Tabel 9. Analisis Teritori Perempuan terhadap Rumah Tinggal

(Sumber : Dokumen Pribadi, 2020)

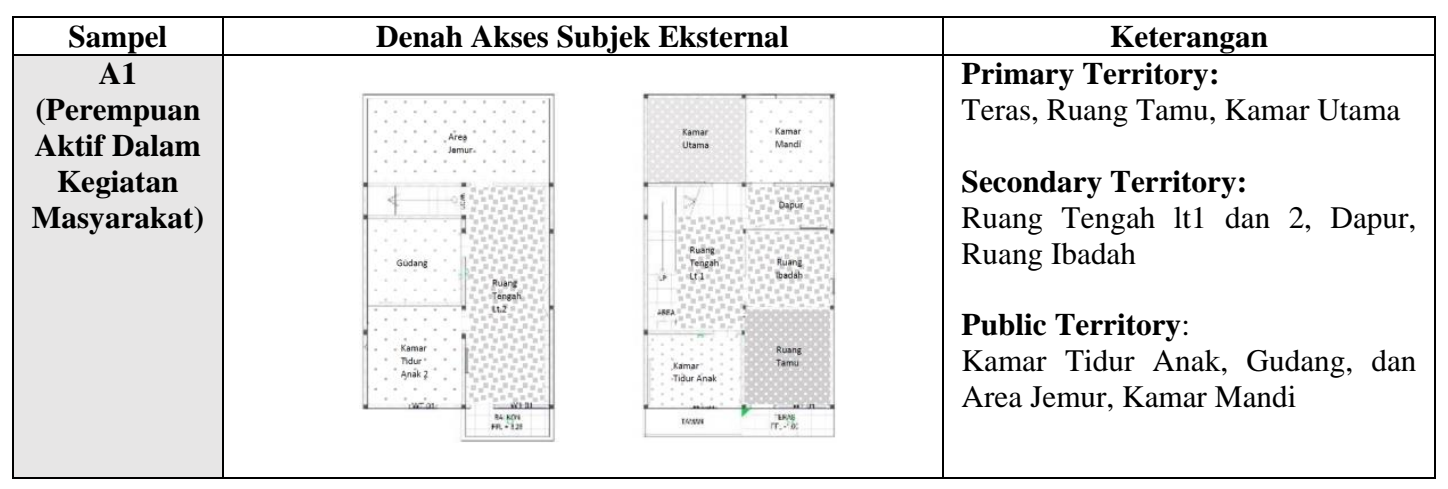




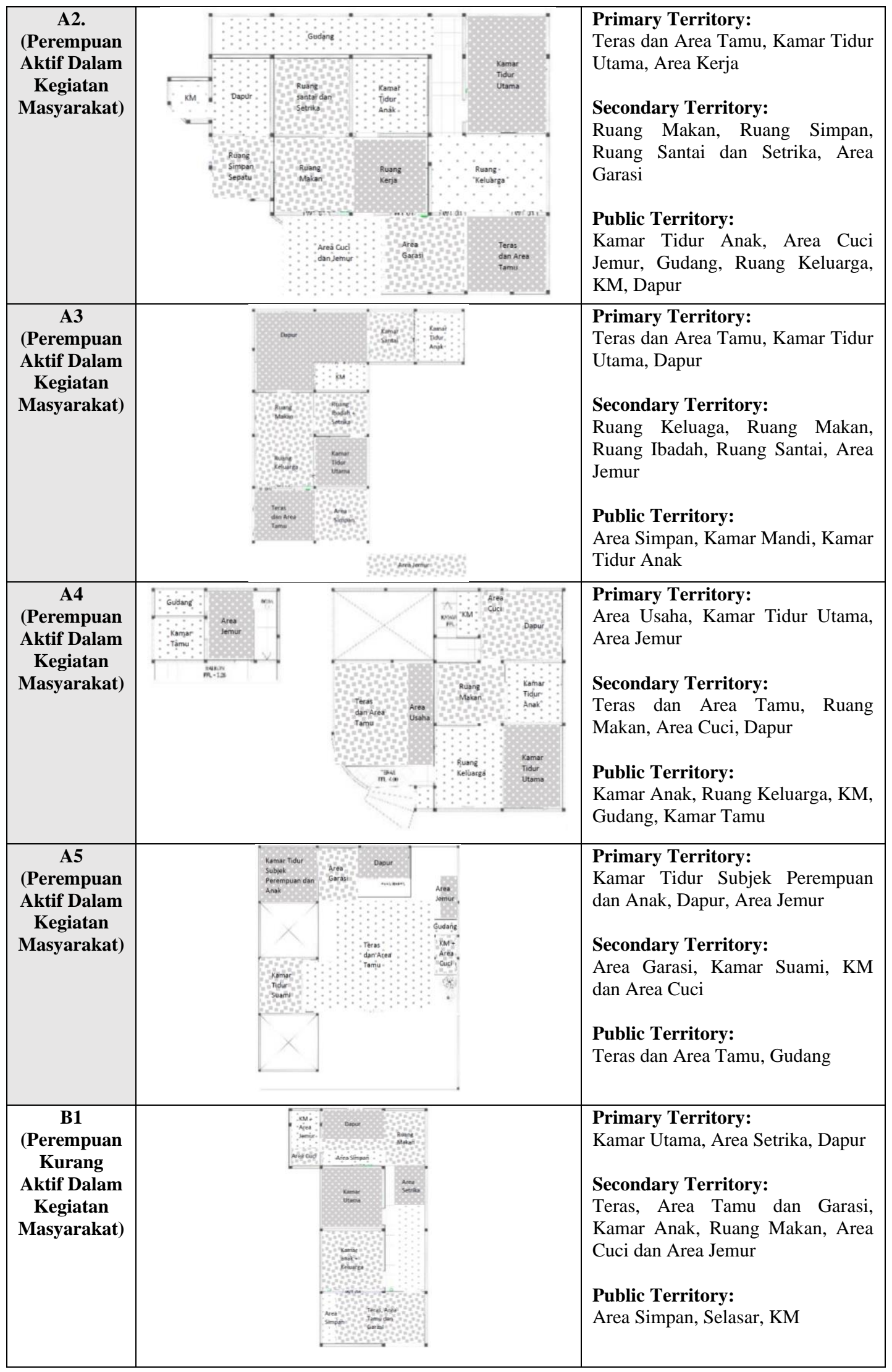




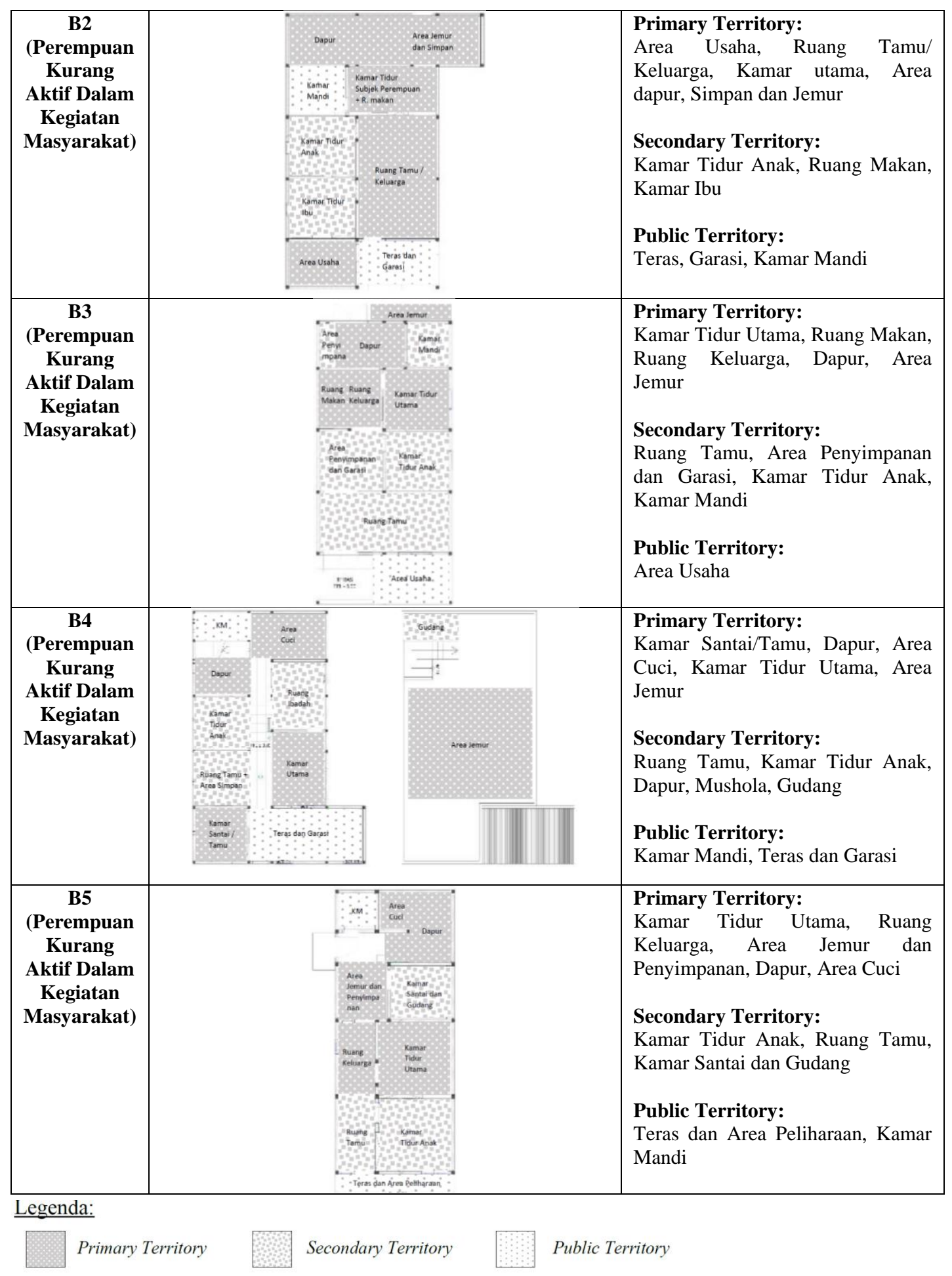

Tabel di atas menunjukkan analisis teritori ruang yang didasarkan melalui ketiga kategori teritori keruangan sehingga dapat menunjukkan perbedaan prioritas ruang personal antar kedua kelompok perempuan dalam rumah tinggal. Perempuan dengan kecenderungan aktif cenderung memiliki lingkup primer yang cenderung lebih kecil daripada perempuan dengan kecenderungan kurang aktif di lingkungan sekitar hunian. Selain kamar tidur yang merupakan area privatnya, Lingkup 
ruangan perempuan dengan sifat teritotial primer dan semi primer nampak pada ruangan yang lebih bersifat terbuka dengan fungsi ruang yang mendukung kegiatan sosial dan kebutuhan kerjanya. Ruang dengan sifat teritori ruang primer pada kelompok ini tampil di area teras, ruang tamu, dan area kerja yang dominan berada di bagian depan hunian. Beberapa kasus khusus didapatkan ruang penerimaan tamu tidak menjadi area primer dan terbagi seperti di hunian A4 dan A5 dikarenakan penggunaan area yang berbagi dengan subjek pengguna lainnya yang juga memiliki kecenderungan aktif di kegiatan sosial. Dilain hal, pada hunian perempuan dengan kecenderungan kurang aktif, ruangan dengan teritori primer dan semi primer dominan berada di area tengah hingga belakang hunian. Walaupun didapati bahwa secara akses dan kontrol akan perempuan pada hunian lebih meluas, namun secara frekuensi lama tinggal serta prioritas profil kegiatan perempuan pada kelompok ini cenderung mendekati area privat dalam hunian.

\section{Simpulan}

Akses dan kontrol perempuan terhadap rumah tinggal akan selalu berbeda. Terdapat beberapa faktor yang dapat mempengaruhi bentuk serta besaran profil akses dan kontrol perempuan terhadap rumah tinggalnya. Seperti halnya faktor lingkungan yang turut memberi pengaruh terhadap implementasi terhadap desain, kegiatan dan sifat keaktifan perempuan pada lingkungan sekitar hunian juga turut memberikan pengaruh terhadap profil akses dan kontrol perempuan dalam masing-masing ruang dalam rumah tinggal.

Berdasarkan kajian kasus melalui 2 kelompok hunian perempuan dengan kecenderungan keaktifan yang berbeda dalam satu wilayah yang ada di Karangwaru Riverside menunjukkan bahwa terdapat perbedaan profil akses dan kontrol perempuan terhadap rumah tinggalnya. Faktor akan perbedaan profil keaktifan perempuan terhadap kegiatan sosial yang ada diluar hunian turut membawa perbedaan kecenderungan perilaku perempuan di dalam skala akses dan kontrol dalam upaya mengatur atau mengendaliakan ruang dalam rumah tinggalnya. Ditemukan bahwa melalui semakin besarnya keaktifan perempuan di luar huniannya membawa pengaruh terhadap semakin terbaginya profil akses dan kontrol perempuan ruang kepada subjek pengguna ruang lainnya. Perempuan dengan keaktifan yang lebih tinggi melakukan kegiatan di luar hunian dan secara sadar membatasi akses diri terhadap ruang-ruang privat subjek pengguna lainnya. Selain kegiatan akses, dalam kegiatan pengendalian ruang, perempuan dalam kelompok ini cenderung menyerahkan sebagian besar kegiatan kontrol ruang kepada subjek pengguna dominan masing-masing ruang. Hal ini berbeda dengan rumah tinggal dengan perempuan dengan kecenderungan kurang aktif di lingkungan sekitarnya. Perempuan dengan kecenderungan kurang aktif, cenderung memiliki profil akses dan kontrol hunian lebih luas dan menyeluruh. Pada kelompok perempuan ini, secara umum memiliki skala akses dan kendali hingga keruang privat subjek pengguna lainnya.

Secara umum perbedaan profil akses dan kontrol pada masing-masing kelompok perempuan telah menimbulkan perbedaan pembagian teritori ruang dalam rumah tinggal. Melalui stimultan perbedaan profil akses dan kontrol harian perempuan terhadap ruang huninya telah mempengaruhi pola sebaran serta skala teritori dalam rumah tinggal. Skala teritorial yang meliputi area primer, secondary atau semi primer, dan area publik kemudian terbentuk dan mencerminkan pengelompokan ruang atau area prioritas perempuan dalam rumah tinggal. Seperti halnya area prioritas serta pola sebaran area primer dan semi primer dalam hunian perempuan aktif yang cenderung mendekati bagian depan hunian yang merupakan ruang tamu yang juga area kerjanya sedangkan ruang di bagian menengah hingga belakang pada hunian perempuan kurang aktif telah menggambarkan karakteristik dan kebutuhan ruang utama pada masing-masing kelompok. 
Lintas Ruang: Jurnal Pengetahuan \& Perancangan Desain Interior | Vol.9 No1Th. 2021 | Hal.1-13

\section{Daftar Pustaka}

Gifford, R. (2007). Enviromental Psychology: Principle and Practice. Colville: WA: Optimal Books.

Haryadi, B. Setiawan. (2010). Arsitektur, Lingkungan, dan Perilaku. . Ypgyakarta: Universitas Gadjahmada Press.

Hiller, B. (1996). Space is The Machine: a Configurational Theory of Architecture. Cambridge: Cambridge University Press.

Hillier, B., \& Hanson, J. (1984). The Social Logic of Space. Cambridge. New York: Cambridge University Press.

Moleong, L. J. (2010). Metodologi Penelitian Kualitatif. Bandung: Remaja Rosdakarya.

Tandal, Antonius N dan Egam, I Pingkan P. (2011). Arsitektur Berwawasan Perilaku (Behaviorisme). Media Matrasain. 